\title{
16. ve 17. Yüzyıl Türkçe Siyasetnâmelerinde Ortak Temalar ve Siyasetnâmelerin İşlevi
}

\author{
Osman Bayraktar ${ }^{1 *}$, V. Lale Tüzüner ${ }^{2}$ \\ 'İstanbul Ticaret Üniversitesi, İşletme Fakültesi, İ̧letme Bölümü, İstanbul, Türkiye \\ ${ }^{2}$ Istanbul Üniversitesi, İsletme Fakültesi, İnsan Kaynakları Yönetimi Anabilim Dalı., İstanbul, Türkiye \\ ORCID: O. Bayraktar (0000-0003-2502-357), V.L. Tüzüner (0000-0003-2476-3574)
}

\begin{abstract}
Özet
Bu makalede 16. ve 17. yüzyıllarda Türkçe olarak yazılmış toplam 15 siyasetnâme taranarak, eserlerde dile getirilen ortak yönetim problemlerinin neler olduğu ve yazarların bu problemlere nasıl tepki verdikleri sorularına cevap aranmıştır. Makalenin odaklandığı ikinci alan, yöneticiler ve yönetim uygulamaları açısından siyasetnâmelerin işlevinin ne olduğu sorusudur. Araştırmada içerik analizi yöntemi kullanılmıştır. Illk aşamada döneme ilişkin bütün siyasetnameler incelenmiş, işlenen konular içeriklerine göre kodlanmış, sekiz ve daha fazla eserde tekrar eden konular ortak tema olarak kabul edilmiştir. İkinci aşamada, yazarların ifadelerinin altında yatan kavramsal yapı keşfedilmeye çalışıımıştır. Padişahın konumu, timar ve zeamet sisteminin yozlaşması, vezirlerin tutumu, hazine yönetimi, askerin sistemin bozulması, reayanın durumu, kadıların niteliğinin düşmesi ve rüşvetin yaygınlaşması siyasetnamelerdeki ortak temalardır. Yazarların önemli bölümü, problemin kaynağını eski uygulamalardan uzaklaşmış olmaya bağlamakta, dolayısıyla çözüm olarak eski uygulamalara dönülmesini önermektedir. Siyasetnameler, yazıldıkları dönemde hem yöneticilere açısından temel siyaset bilgilerini aktaran kaynaklar hem de gerçek problemlere çözüm üreten metinler olma işlevini görmüşlerdir. Günümüzde, temel yönetim bilgilerini aktarma işlevini yönetim okulları; yönetim problemlerine çözüm önerilerini ise yöneticilerin yanlarında bulundurdukları danışman kadrosu karşılamaktadır. Bu bakımdan, siyasetnâme tarzı eserlerin günümüzde fazlaca karşılığı bulunmamakla birlikte, yönetim bilgisine ve yazma kudretine sahip yazalar her zaman etkileyici eserler ortaya koyabilirler. Günümüzde de bu yazım tarzını deneyen yazarların olduğu görülmektedir.
\end{abstract}

Anahtar Kelimeler: Siyasetnâme, kamu yönetimi, Osmanlı yönetim sistemi, siyasetnâmalerin işlevi.

\section{Common Themes in the 16th and 17th Century Political Texts and the Function of These Texts}

\begin{abstract}
In this article, total of 15 political texts written in Turkish in the 16 th and 17 th centuries were scanned and answers to the questions of the common management problems expressed in the works and how the authors reacted to these problems were sought. The second area the article focuses on is the question of what the function of political texts in terms of managers and management practices. In the research, the content analysis method was used. In the first stage, all the political texts were examined, the themes were coded, and the issues in eight works and more were accepted as common themes. In the second stage, the conceptual and real structure behind the linguistic expression expressed by the authors was tried to be interpreted. The status of sultans, corruption of the timar and sergeancy system, management of the treasury, the attitude of viziers, the disruption of the soldier's system, the decline of the quality of the kadis and bribery are common themes. Most of the authors attribute the source of the problem of being distanced from old practices and therefore suggest returning to old practices as a solution. Although politicsstyle works do not have much value today, although, writers who have management knowledge and writing power can always produce impressive works.
\end{abstract}

Keywords: Political treatise, public administration, Ottoman administration system, the function of political treatise.

\section{Gíriş}

Siyasetnâmeler, dönemin yöneticilerine yol göstermek üzere kaleme alınmıș eserlerdir. Bilinen ilk siyasetnâme örneği, Hindistan' da Beydeba tarafından M.Ö. 300'lü yıl-

*Yazıșma Adresi / Address for Correspondence: O. Bayraktar, Email: obayraktar@ticaret.edu.tr

Geliş Tarihi / Received Date: 08.08.2021

Kabul Tarihi / Accepted Date: 15.11.2021

Doi: 10.32329/uad.980290 larda yazıldığı tahmin edilen Kelile ve Dimne'dir. Masal formundaki eser bir eğitim malzemesi olarak tasarlanmıştır. Snskritçe yazılan bu eser sonraki asırlarda Farsça ve Arapça'ya çevrilerek yöneticiler tarafından her zaman ilgiyle karşılanmıştır (Karaismailoğlu, 2002, s. 210). Doğuda en fazla siyasetnâmenin yazıldığı ülke, büyük bir devlet geleneğine sahip olan Fars İmparatorluğu'dur. Fars dilinde Siyasetnâme yazımı toplum Müslüman olduktan sonra de artarak devam etmiştir. Diğer yandan çok erken dönemde Arapça siyasetnâmeler de yazılmaya başlanmıştır. Selçuklular'da Farsça dilinde siyasetnâme 
yazılması sürerken, Osmanlılar'da hem Farsça ve Arapça yazılmış eserler Türkçeleştirilmiş hem de Türkçe olarak yeni siyasetnâmeler yazılmıştır.

Siyasetnâmeler bir yöneticide bulunması gereken ideal özellikleri tasvir eder. 16. yüzyılda, Lütfi Paşa tarafından yazılan Asafnâme ile birlikte siyasetnâme geleneği içerisine ıslahatnâme olarak adlandırılan yeni bir yazım tarzı ortaya çıkmıştır. Siyasetnâme türünün özellikleri korunmakla birlikte, sslahatnâmelerde, gerçek hayattaki problemler için somut çözüm önerileri sunulmaktadır (Yilmaz, 2003, s. 300).

Siyasetnâmelerle ilgili zengin bir yazın bulunmaktadır. Dinçer (2018) Doğu ve İslam medeniyeti havzasında ortaya konulan siyasetnâmeleri yüzyıllık dönemlere ayırarak incelemiştir. Yazar, eserinin son bölümünde siyasetnâmelerle aktarılan kültür ve düşünce birikiminin günümüz yönetim anlayışına katkı ve değerini tartışmaktadır. Blaydes, Grimmer ve McQueen (2018) İslam medeniyet coğrafyası ile Avrupa medeniyet coğrafyasında ortaya konulan 18 siyasetnâmeyi içerik tarama yöntemi ile karşılaştırarak benzer ve ayrışan yönlerini ortaya koymuşlardır.

Bir araştırmada, sadece İstanbul kütüphanelerinde 269 siyasetnâme olduğu belirtilmiştir (Yılmaz, 2009, s. 308). Bu çalışmada, 16. ve 17. yüz yılları arasında Türkçe yazılmış siyasetnâmeler incelenmiștir. Araştırma alanının Türkçe yazılmış eserlerle sınırlandırılması, ortaya konulan düşüncelerin, daha somut toplumsal gerçeklere dayanmış olacağı varsayımıdır. İnceleme alanı olarak seçilen iki yüzyıllık süre, Osmanlı Devleti'nin, en parlak kabul edilen döneminden sonra ilk defa bir takım yönetim problemlerinin ortaya çıkması ve aydınların bu problemlere çözümler üretme çabaları açısından ilgi çekicidir. Toplumsal yapıdaki bu değişim, siyasetnâme yazım tarzını da etkilemiş, genel nitelikli nasihatnâmelerden, günün problemlerine özgü çözümler üreten islahatnâme tarzı içerikler üretilmeye başlanmıştır.

\section{YÖNTEM VE ARAŞTIRMA SORULARI}

Araştırmada tümevarım nitel içerik analizi ve söylem analizi yöntemleri birlikte kullanılmıştır. Nitel içerik analizi, metin verilerinin sistematik olarak tasnif edilerek öznel biçimde yorumlanması yöntemidir. İçerik analizinin amacı, çalışılan konu ile ilgili yorum ve kavrayış yeteneği kazandırmaktır (Hsieh ve Shannon, 2005, s. 278). Nitel içerik analizi tümden gelim veya tüme varım biçiminde yapılabilir. Her iki seçenekte de içerik analizi üç aşamadan oluşur: Hazırlık, organizasyon ve sonuçların raporlanması (Elo vd., 2014, s. 3). Tümevarım nitel içerik analizinde araştırma soruları, veri toplama ve analiz süreçleri için yol göstericidir. Ancak verilerin değerlendirilmesi esnasında yeni temalar ve sorular ortaya çıkabilir (White ve Marsh, 2006, s. 35). Toplanan veriler, ortak temalar oluşturacak biçimde çözümlenerek, yönetim bilimi açısından değerlendirilebilir çıktılar oluştu- rulmaya çalıșılmıştır. Belirlenen eserler önce içerik yönü ile analiz edilmiş, ikinci olarak eserlerin dönemin siyasal koşulları ile ilişkisi kurulmaya çalıșılmıştır.

İncelemede aşağıdaki sorulara cevap aranmıştır:

- İncelenen eser, siyasetnâme geleneğinin hangi türünde yer almaktadır?

- Eser, yönetim problemlerini nasıl ele almış, hangi yönetimsel sorunları öne çıkarmış ve bu sorunlara hangi çözümleri üretmiştir?

- Siyasetnâmelerde ele alınan ortak problemler nelerdir?

- Eserin kendi dönemi ve sonraki dönemler için etkisi nedir?

- Siyasetnâme dilinin günümüz yönetim düşüncesi ve uygulamaları açısından karşılığı nedir?

\section{XVI. YÜZYILDA OSMANLI DEVLET ANLAYIŞI, DEVLET TEŞKILATI VE ÇEVRESEL GELIŞMELER}

Farklı değerlendirmeler olsa da Osmanlı devlet yönetim anlayışının ve yönetilenlerle kurduğu ilişkinin özünde dini değerler bulunmaktadır. Bu anlayışa göre, sultan yeryüzünde Allah'ın gölgesi ve mazlumların sığınağıdır. Hukuk sistemi de kaynağını dinden alır. Kur'an'ın getirdiği hükümlere, sultan dâhil herkes uymak zorundadır. Kur'an'ın açık bıraktığı alanlarda hükümdarlar istedikleri gibi düzenleme yapabilir ki bu alan oldukça geniştir. Devletin temelde üç işlevi bulunmaktadır. Vergi toplamak, adaleti gerçekleştirmek ve halkın güvenliğini sağlamak. Bu sistemde yasama, yürütme ve denetim işlevlerinin tümü sultanın sorumluluğundadır. Adaleti sağlama ve sistemin denetimi şeyhülislama bağlı kadılar aracılığıyla gerçekleştirilir. Kadıların, köylere kadar uzanabilen yetkilendirdikleri adamları bulunmaktadır. Yürütme ve güvenlik işlevleri vezirler tarafından gerçekleştirilir. Eğitim, sağlık, bayındırlık gibi hizmetler devletten bağımsız olarak vakıflar tarafından yürütülür.

Toprakta özel mülkiyet sınırlıdır. Mülk, esas olarak devlet adına padişahın olduğu için köylüler, dini değerlere göre tanımlanmış vergilerini ödeyerek bu toprakları kullanma hakkını elde ederler. Vatandaşlar genel olarak Müslüman ve Müslüman olmayanlar olarak ikiye ayrılır. Müslüman olmayan vatandaşlardan cizye adı altında vergi alınır, buna karşılık devlet onların güvenliğini korumayı garanti ederler.

Sınırlı sayıda sabit asker ve sarayda görevli memurların dişında, yüksek devlet görevlileri doğrudan devlet hazinesinden maaş almaz, buna karşılık kendilerine belli toprakların vergisini toplama hakkı verilirdi. Bu bağlamda, toprak yönetimi, hazine yönetiminin esaslı bir unsurudur. Veziriazam, beylerbeyi, kazasker gibi üst düzey yöneticiler, istihdam ettikleri memurları kendileri seçer, maaşlarını kendileri öderlerdi. Doğrudan devletten maaş alanların dışında kalan asker grubu da aynı yöntemle, 
devletin yetkilendirdiği, asker kökenli kişiler tarafından vergi karşılığı olarak hazır bulundurulurdu. Savaş zama$\mathrm{n} ı$ bu askerler istenilen yöne sevk edilerek orduya katılirdi.

16. yüzyılın ikinci yarısından itibaren meydana gelen dört büyük olay Osmanlı devlet ve toplum dengesini derinden sarsmıştır. Bunlar nüfus artışı, mali buhran, askeri sistemdeki değişme ve Celali fetretidir (Yücel, 1988, S, X-Xiv).

Nüfus artması. 16. yüzyılda Osmanlı imparatorluğundaki toplam nüfus önemli ölçüde artmış, buna karşılık tarım arazisi aynı oranda genişlemediği için Anadolu'da çok sayıda insan köylerdeki toprağını terk etmek durumunda kalmıştı. Levent, gurbetçi gibi isimlerle anılan bu insanlardan çok azı başka yerlerde iş bulabilmişti, önemli bölümü büyükşehirlerin kıyılarına gelip yerleşmiştiler veya Rumeli'ye geçtiler. Aynı yıllarda, Anadolu'daki şehirlerde, medreselerdeki eğitimlerini tamamlayıp iş bulamayan çok sayıda, suhte adı verilen genç insan birikmişti. Bu iki grup Celali isyanları olarak isimlendirilen ayaklanmaların aktörleri oldular (İlgürel, 1993, s. 253).

Mali buhran. 1580 yılından itibaren, İtalyanlar kanalıyla Latin Amerika'dan bol miktarda ucuz gümüş para Osmanlı devletine da akmaya başladı. Latin Amerika gümüşünün gelişiyle, Osmanlı akçesi hızla değer kaybetti, halkın satın alma gücü düștü, devletin vergi gelirleri azaldı, gelirler giderleri karşılayamaz oldu (Naki, 2016, s. 238). Fiyat artışı en fazla defterlere kayıtlı sabit gelirli dirlik ve ulufe sahiplerini etkilemiştir. Mali darlık nedeniyle sefer çağrısına olumlu karşılık veremeyenlerin timarlarına el konulmuş, boşta kalan kişiler de isyancılar arasına katılmıştır. Geçim darlığı, eyaletlerdeki memurlar, yani ehl-i örf arasında da rüşvetin yaygınlaşmasına sebep olmuştur. Devletin gelirleri azaldıkça avârız vergileri ihdas olunmuştur (Yücel, 1988, s. X11).

Askeri sistemdeki değişme. 1559'da Şehzade Bayezid'in isyanından sonra, Anadolu'da, Altı-Bölük olarak adlandırılan yeniçeri askerleri Anadolu'da garnizonlar kurarak yerleşik hale gelmiştir. Sabit maaşlı asker sayısı artarken timarlı sipahi ordusu ise önemini kaybetmiştir. İmtiyazlı bir grup olan yeniçeriler halkın üzerinde tam bir baskı gücüne dönüşmüşlerdir.

Celali fetreti. III. Mehmed'in, 1596'da gerçekleşen Eğri seferi hazırlığı sırasında, Hüseyin Paşa ile Karayazıcı'ya Orta Anadolu'da asker toplama yetkisi verilmişti. Ancak bu kişiler, etrafına topladıkları kişilerle devlete isyan ederek, halktan zorbalıkla para ve erzak toplamaya başladılar. 1598' den itibaren büyük topluluklar haline şehir ve kasabalara saldırmaya başladılar. Celali liderlerinden Karayazıcı1602' de öldürüldü, Deli Hasan, hükümetle anlaşarak Bosna'ya beylerbeyi olarak gönderildi. Buna rağmen hareket durmadı. 1610'da Büyük kaçgün olarak adlandırılan büyük göç olayı meydana geldi (Yücel, 1988).

Araştırma kapsamında, 16. ve 17. yüzyıllarda Türkçe olarak yazılmış ve basılmış siyasetnâmeler incelenmiştir. Alanyazında ilki 1537 yılında, sonuncusu1675 yılında yazılmış, ikisi aynı yazara ait matbu 15 siyasetnâme olduğu belirtilmektedir. İncelenen eserlerin yazarları, yazıldıkları tarih, kime takdim edildiği bilgileri Tablo 1.'de gösterilmiştir. İncelenen eserlerden Ahlak-ı Alâî nasihatnâme, diğerleri ise ıslahatnâme tarzındadır.

\section{BULGULAR: 16. VE 17. YÜZYIL SIYASETNÂMELERINDE ORTAK TEMALAR}

Konu başlıklarına göre yapılan kodlamalar incelendiğinde, Tablo 2'de gösterilen 11 konunun, 15 eserin en az sekizinde ortak tema olarak varlığını sürdürdüğü belirlenmiştir.

Tablo 1. Araştırma Kapsamında İncelenen Eserler

\begin{tabular}{|c|c|c|c|c|}
\hline Eser & Yazarı & Mesleği & Yıl & Takdim Edilen Kişi \\
\hline Ahlâk-ı Alâî & Kınalızâde Ali Çelebi & Kazasker & 1537 & Veziriazam Semiz Ali Paşa \\
\hline Asafnâme & Lütfi Paşa & Vezir & 1541 & -.- \\
\hline Mi'râcü'l-Eyâle & Âşık Çelebi & İlmiye sınıfından & $1566-1572$ & Sultan II. Selim \\
\hline Hırzül-Mülûk & - & Bürokrat & 1580 & Sultan III. Murad \\
\hline Nushatu's Selâtîn & Gelibolulu Mustafa Âlî & İlmiye sınıfından Defterdar & 1581 & $\ldots$ \\
\hline Usûlüll hikem fî nizâmi'l âlem & Hasan Kâfî & Müderris & 1596 & -.- \\
\hline $\begin{array}{c}\text { Kavânîn-i Âl-i Osmân der Hulâsa-i } \\
\text { Mezâmîn-i Defter-i Dîvân }\end{array}$ & Ayn Ali Efendi & Defterdar emini & 1602 & Sultan III. Mehmed \\
\hline Kitâb-i Müstetab & - & Bürokrat & 1620 & Sultan II. Osman \\
\hline Risale & Koçi Bey & Danışman & 1631 & Sultan IV. Murad \\
\hline Kanûn-nâme-i Sultânî li Azîz Efendi & Azîz Efendi & Danışman & $1632-1633$ & Sultan IV. Murad \\
\hline Risale & Koçi Bey & Danışman & 1641 & Sultan I. İbrahim \\
\hline $\begin{array}{c}\text { Kanun-i Osmani Mefhum-ı Defter-i } \\
\text { Hakani }\end{array}$ & Avni Ömer Efendi & Reisülküttab & 1642 & Sultan I. İbrahim \\
\hline $\begin{array}{l}\text { Kitabu Mesâlihi'l Müslimîn ve Menafi'il } \\
\text { Mü'minîn }\end{array}$ & - & İlmiye sınıfından Danışman & $1639-1643$ & $\begin{array}{l}\text { Veziriazam Kemankeş } \\
\text { Kara Mustafa Paşa }\end{array}$ \\
\hline Düstûru'l amel li Islahi'l-halel & Kâtib Çelebi & Bürokrat & 1653 & Sultan IV. Mehmed \\
\hline Telhîsü'l-beyan fi kavânîn-i Âl-i Osmân & Hezarfen Hüseyin Efendi & Bürokrat & 1675 & -.- \\
\hline
\end{tabular}

Kaynak: Tablo araştırmacılar tarafından geliştirilmiştir. 
Siyasetnamelerde en çok üzerinde durulan konu timar ve zeamet sistemindeki bozulmadır (\%80). İkinci sırada padişahın tutumu ve hazinenin yönetimi ele alınmaktadır (\%73). Üçüncü sırada veziriazamların davranışları, ulemanın ve reayanın durumları ve vergi uygulamaları işlenmektedir (\%66). Dördüncü derecede adalet ve askerlik sistemleri ele alınmaktadır (\%60). Son olarak rüşvet konusu birçok siyasetname yazarının ortak gündemini oluşturmaktadır (\%53). Aşağıdaki paragraflarda ortak konuların ayrıntıları üzerinde durulacaktır.

Tablo 2. 16. ve 17. Yüzyıl Siyasetnâmelerinde Ortak Temalar

\begin{tabular}{|c|c|c|}
\hline Tema & Eser Sayısı & $\%$ \\
\hline Padişah & 11 & 73 \\
\hline Veziriazam & 10 & 66 \\
\hline Askerin durumu & 9 & 60 \\
\hline Timar ve zeamet sistemi & 12 & 80 \\
\hline Ulemanın durumu & 10 & 66 \\
\hline Hazine Yönetimi & 11 & 73 \\
\hline Reaya & 10 & 66 \\
\hline Vergi & 10 & 66 \\
\hline Adalet & 9 & 60 \\
\hline Rüşvet & 8 & 53 \\
\hline
\end{tabular}

Kaynak: Tablo araştırmacılar tarafından geliştirilmiş̧tir.

\subsection{Timar ve Zeamet Sistemi}

Osmanlı'da harça arazisi, öşür arazisi ve memleket arazisi olmak üzere üç arazi çeşidi bulunmaktadır. Arazi hukuku, Şeyhülislam Ebussud Efendi'nin fetvaları ile şekillenmiştir. Âşık Çelebi (2018) bu fetvaları ayrıntıları ile naklederek yorumlamaktadır. Ayn Ali Efendi (1962), III. Murad'in isteği ile hazırladığı eserinde, Osmanlı Devleti toprak sistemini çok ayrıntılı biçimde incelemiştir. Bir yer fethedildiğinde, sultan bu araziyi bölerek ganimet olarak dağıtır veya orada yaşayan kimseler Müslüman olur da fethedilen arazi yine onların kullanımına bırakılırsa bu öşür arazisidir. Bir yer fethedildiğinde, oranın yerlilerine, İslam'a gelmeden araziyi kullanmalarına izin verilirse buna öşür değil, haraç arazisi denilir. Çünkü öşür, ibadete bağlı bir nitelemedir. Öșür arazisi ve haraç arazisi kullananların mülküdür, alınıp satılabilir, miras bırakılabilir. Rumeli arazisi ise ne öşür ne de haraç arazisidir; mülkiyeti devlete aittir, buna memleket arazisi denilir. Parçalara ayrılan arazi, yüksek memurlar ve sipahiler tarafından işletilir. Alınıp satılamaz, miras bırakılamaz. Aynı tanımlamalar daha sonra Hezarfen (1988, s. 108) tarafından da tekrar edilmiştir. Ayn Ali Efendi'nin eseri kendi dönemlerinde uygulama rehberi niteliği kazanmıștır (İpşirli, 1999, s. 170; Afyoncu 2013, s. 95).

Timar ve zeamet sistemi, bütün siyasetnâme yazarlarının üzerinde durduğu, Osmanlı yönetim ve ekonomik yapılanmasının en temel birimidir. Askeri sistem, üretim kapasitesi, reayanın refahı, vergi gelirleri hep timar ve zeamet üzerine bina edilmiştir. Rüşvetin artması, köylünün çift bozup toprağını terk etmesi, savaş esnasında yeterli askerin tedarik edilememesi, hazine gelirlerinin azalması temelde timar sisteminde yaşanan problemlerden kaynaklanmaktadır. Kanun-i kadim, timarın, kılıç hakkı olarak sipahilere ve onların oğullarına verilmesini öngörmektedir. Kınalızâde (2014, s. 606) çok erken dönemde, 1541 'de, askerlik hakkı olarak elde edilen timarın, sipahi oğluna bırakılmamasının hazinenin boşalmasına yol açacağı uyarısında bulunur. Lütfi Paşa (2017, s. 37) aynı uyarıyı tekrarlar. Hırzü'l-Mülûk yazarı (1988, s. 160) 1580 'de, Osmanlı toplum düzeninin sürdürülebilmesi için devletin elinde, yeni ihtiyaçlar durumunda tahsis edeceği arazilerin bulunması gerektiğini belirtmiștir. Oysa kudretli vezirler, bürokrasi üzerindeki gücünü kullanarak çok kıymetli arazileri devletin kontrolünden çıkarmakta, sonuç olarak hem reaya yoksullaşmakta hem de hazine geliri azalmaktadır. Mustafa Ali (2015, s. 146), vezir ve beylerbeylerinin, kanun-i kadime aykırı olarak, kendi istihdam ettikleri adamlara timar ve zeamet verdiklerini belirtmektedir. Kitâb-i Müstetab yazarı (1988, s. 4), sistemin çökme sebebi olarak, vezirlerin padişahın onayını almadan dirlik vermelerini gösterir. Ayn Ali (1962, s. 109), timar ve zeamet sisteminin bozulmasını, timar ve zeamet sahiplerinin işinin başından ayrılması, defter kayıtlarının düzgün ve güncel olmaması ve denetimin yapılamamasına bağlar. Koçi Bey (2008, s. 51), sistemin 1584 yllına kadar düzgün işlediğini, bu tarihte Özdemiroğlu Osman Paşa'nın bazı kimseleri ödüllendirmek için geleneğe aykırı olarak kendilerine timar hakkı vermesi ile sistemin bozulduğunu belirtmektedir. Hem Hirzü'l-Mülûk yazarı (1988, s. 156) hem de Koçi Bey (2008, s. 53), problemin kaynağının, daha önce beylerbeyinde olan timar verme yetkisinin veziriazamlara geçmiş olmasında görürler. Çözüm olarak, yeniden, kanun-i kadime uygun olarak timar dağıtımı konusunda yetkinin beylerbeyine verilmesini önerirler. Koçi Bey (2008, s. 87), bunun nasıl yapılması gerektiğine dair ayrıntılı bir uygulama planı sunmaktadır. Koçi Beyin tahminine göre bu düzenlemelerin yapılmasından sonra yüzbinden fazla seçme zeamet sahibi ve timar erbabı ortaya çıkacak ve dört yüz, beş yüz bin kişilik bir askeri güç kapasitesi oluşacaktır.

\subsection{Padişah}

Padişah veya sultan teması siyasetnâmelerde, padişahın konumu ve görevleri olmak üzere iki yaklaşımla ele alınır. Padişahın konumu ve meşruiyeti hiçbir siyasetnâmede tartışma konusu yapılmaz. Kınalızâde (2014, s. 482-599), padişahın gerekliliğinin kuramsal gerekçesini açılar. İnsanların birlikte uyum içinde yaşamalarının ancak 'siyaset-i uzma' ile mümkündür. Büyük siyasetin hayata geçmesi üç koşulun bir araya gelmesi ile gerçekleşir: ilahi kanun (nâmus-ı şâri), devlet başkanı (hâkim-i mâni) ve para (dînar-1 nâfi). Erdemli toplumda devlet başkanı halife veya imamdır. Saltanat ve padişahlık bazı kimselere bahşedilmiş ilahi bir armağandır. Hırzü'l-Mülûk yazarı (1988, s. 173), armağan yerine 'büyük emanet' demeyi tercih eder. Padişah için yaygın olarak Allah'ın gölgesi sıfatı yazarlar tarafından yaygın olarak kullanılır (Kınalızade: 549; Mustafa Âlî, s. 285; Hasan Kâfi, s. 
247; Aziz Efendi, 1980, s. 27). Kâtip Çelebi (2016, s. 155), bu yaklaşıma; bütün mülk, hazine ve askerin Allah'a ait olduğunu, padişahın mecazî olarak onun halifesi olduğu açıklamasını ekler. Âşık Çelebi (2018, s. 41), padişahın konumunu belirlemek için peygamberlerin misyonuna işaret eder. Peygamberler, ilahi hükümleri tebliğ etmiş, sultanlar ise bunları hayata geçirmişlerdir. Son peygamber Hz. Muhammed bu iki işlevi şahsında birleştirmiştir. Peygamberden sona icraat yükümlülüğü sultanlara kalmıştır. Ancak devletin varlığını devam ettirilmesi, ulemanın varlığına bağlıdır.

Siyasetnâme yazarları, padişahın konumunu tartışmaya açmazken birtakım davranışlarını ise eleştirmektedirler. Örneğin Kitab-i Müstetab (1988) yazarı, Kanuni’nin, İbrahim Paşa ve Rüstem Paşa'nın veziriazamlığa atanmasında geleneksel kariyer yolunu bozmasını; Koçi Bey (2008, s. 81), Kanuni'nin damadı Rüstem Paşa ve kızı Mihrimah Sultan'a çok geniş arazi vermesini eleştirmektedir. Ancak padişaha yönelik eleştiriler her zaman bu kadar açık değildir. Yazarların padişah ile ilgili eleştirilerini, doğrudan değil, padişahta olması gereken nitelikleri ortaya koyarak dolaylı biçimde yaptıkları söylenebilir (Kınalıâde, 2014, s. 546-566; Mustafa Âlî, 2015, s. 313342). Hezarfen'in (1988, s. 113), beylerbeylerinin halka yaptıkları zulümleri sıraladıktan sonra, "Bütün bu işler padişahtan sorulur, imamet, hitabet ve hükumet hakkı padişahındır, onlar ancak padişahın vekilidir" tarzındaki ifadesi, dolaylı olmaktan çıkıp, doğrudan padişahı hedef almaktadir.

\subsection{Hazine Yönetimi}

Kınalızâde (2014, s. 482), 'büyük siyaset'i yürütmenin üç şartından birisinin hazineye (dinar-ı nâfi) sahip olmak olduğunu belirtir. Âşık Çelebi (2017, s. 200), İslam devleti hazinesinin gelir kaynaklarını ve bu kaynakların nerelere harcanmasının mümkün olduğuna dair ayrıntılı bir tasnif yapmaktadır. Osmanlı devlet sisteminde, iç hazine ve dış hazine olmak üzere ikili bir sistem bulunmakta idi. İç hazine, doğrudan padişahın kullanımına tahsis edilen kaynaklardır. Örneğin Mısır hazinesi, padişaha 'cep harçlığı' olarak tahsis edilmiştir (Lütfi Paşa 2017, s. 75). Dış hazine ise, devlet çalışanlarının ve başka giderlerin karşılandığı, defterdarın yönetimindeki devlet hazinesi idi. Dış hazinenin yetmediğinde, iç hazine kaynaklarının kullanıldığı durumlar da olmuştur. Cami, medrese, külliye gibi büyük büyük yatırımlar, padişah yaptırıyorsa iç hazineden; vezir, paşa gibi diğer yöneticiler tarafından yaptırılıyorsa kendi hazinlerinden karşılanıyor idi. Dolayısıyla en büyük ve düzenli gider kaynağı maaşlı memur ve askerlerdi. Timar sistemi yapılanması ile Osmanlı, maaşlı asker sayısını uzun yıllar asgari düzeyde tutmuş, sadece yeniçeri askerleri maaş almakta idi. Hem yüksek düzeyli yöneticiler hem de yeniçeriler emekli olduklarından kendilerine belli bir gelir ve maaş tahsis edilirdi. Lütfi Paşadan başlamak üzere, bütün siyasetnâme yazarları hazinenin gelir gider durumu ile ilgilenmişlerdir. Lütfi
Paşa (2017, s. 43), iyi bir hazine yönetimi için, sık maaş arttırılmaması, çalışanları emekli etmekte titiz davranılması gerekliliğini vurgular. Beylerbeyi, defterdar, kadı ve kazaskerlerin emeklilik gelirlerinin ne kadar olması gerektiğine dair ayrıntılı liste verir. Hazinenin gelir kaybı olmaması için mukataaların iltizam usulü yerine emanet usulü ile verilmesini önerir. Hazine yönetiminde birinci ilke, gelir her zaman giderden fazla olmamalıdır. Sadrazam bunu gerçekleştirebilmek için ulufeli (maaşli) asker sayısını çoğaltmaktan kaçınmalıdır. "Asker az gerek, uz gerek". Yani askerin sayısı az ama niteliği yüksek olmalıdır. On beş bin maaşlı askerin çok olduğunu belirtir. Hazine yönetimi ile bağlantılı olarak maaşlı asker sayısının çokluğu sonraki yazarları da meşgul eden bir problem olacaktır (Aziz Efendi 2008, s. 29). Koçi Bey (2008, s. 56), Lütfi Paşa' dan yaklaşık doksan yıl sonra, 1631'de IV. Murad'a sunduğu risalede, maaşlı asker sayısını 92.216 kişi olarak kaydetmektedir. Ayn Ali (1962, s. 35) ve Hezarfen Hüseyin Efendi (1998, s. 152), asker sayıları ve aldıkları maaşlara ilişkin ayrıntılı tablolar vermektedirler.

Hırzü’l Mülûk yazarı (1988, s. 187), hazine yönetimine hâkim olabilmek için, padişahın ülkedeki bütün memuriyetleri ve gelirlerinin ne olduğunu bilmesi gerektiğine dikkat çekmektedir. Kitâb-i Müstetab yazarı (1988, s. 4), asker sayısının çokluğu nedeniyle maaşlarının ödenmemesinin Celali isyanlarına yol açtığını belirtmektedir.

Mustafa Âlî (2015, s. 336), saraydaki israfa dikkat çeker. Bu bağlamda, Eski Saray ve Yeni Saray dururken başka sarayların yaptırılmasını israf olarak değerlendirir. Yazarın sarayda israf kapısı olarak, saray mutfağının denetimsizliğini ve saraya kumaş dokuyan ustaların hem sayı olarak kalabalık hem de ücretlerinin çok yüksek olmasını zikreder ve bunların kazançlarına sınır konulmasını önerir.

Aziz Efendi (1985, s. 29), giderleri azaltmak için israftan kaçınılması, maaşlı asker sayısının azaltılması ve kendilerine çok yüksek gelir getiren arazi tahsisi yapılmış olan vezir sayısının yediden, Kanuni döneminde olduğu, dörde düşürülmesini önermektedir. Kâtib Çelebi (2016, s. 151), devletin yaşı itibariyle giderleri düşürmenin gerçekçi bir görüş olmadığını, bu durumu kabullenerek çözüm üretilmesi görüşündedir.

\subsection{Veziriazam}

Osmanlı yönetim sisteminde icraatta en büyük güç sahibi olan kişi veziriazamdır. Siyasetnâmelerin bir kısmı doğrudan veziriazamlar dikkate alınarak yazılmıştır. Lütfi Paşa'nın Asafnâme'si bu niteliktedir. Diğer siyasetnâmelerde de vezirin sahip olması gerekli özellikler ve uygulamadaki aksaklıklar daha çok vezirler üzerinden tartışılmıştır. Lütfi Paşa (2017, s. 32), veziriazamın kişilik özelliklerini sayarken birinci özellik olarak, padişah karŞısında sözünü sakınmamasını, ikinci özellik olarak sır tutmayı zikreder. Veziriazam görevini yaparken azledilmekten korkmamalı, uygun olmayan işler yapmaktansa 
azledilmeyi göze alıp halkın arasında saygınlığını korumalıdır. Vezareti dört halifenin makamına benzeten $\mathrm{H}$ r $z \ddot{u} l$ l-Mülûk yazarının (1988, s. 173) veziriazamda aradığı nitelikler çok yüksektir. Bu göreve getirilecek kişi dindar, adaletli, maddi hırslardan uzak, hilekârlık düşünmeyen, Farsça ve Arapça bilen, yazı yazmada maharetli, güzel görünümlü ve feraset sahibi olmalı, başarılı yönetim uygulamaları ile ülkeyi düşmanların kötülüklerinden ve eşkıya fesadından koruyabilmelidir. Veziriazam, memleketin her yanındaki yöneticileri bilmeli, halkın mutluluğu için durmaksızın çalışmalıdır (Mustafa Âlî 2015, s. 284).

Hırzü'l-Mülûk yazarı (1988, s. 170), veziriazamların, yetkilerini kötüye kullanarak, kendilerine ve yakınlarına kanuna aykırı biçimde zeametler tahsis etmelerinin olumsuz sonuçlarını genişçe tartışır. Bunu önlemenin bir koşulu olarak, evladı ve akrabası çok olana vezirlik görevi verilmemesini önerir. Padişah, daha şehzadelik döneminde bürokrasi kadrosunu iyi tanımalı, saltanata geldiğinde, yetenekli gördüğü kişileri, kararlılıkla vezirlik görevine getirebilmelidir. Kitâb-i Müstetab yazarı (1988, s. 29), nizam-ı âlemin bozulmasının ve hazinenin zayıflamasının, en büyük sebebinin, 25 yıldan bu yana, veziriazamların, dirlik verirken padişahın onayını almamaları olduğunu belirtir. "Balık baştan kokar" meseli gereğince, veziriazam katındaki bozulma, bütün devlet yapısını etkilemektedir. Koçi Bey, liyakatsiz veziriazamların tayinini, padişahların vezir atamasında kanun-i kadimden ayrılmış olmasına bağlar. Kötü örneği başlatan ise Kanuni Sultan Süleyman'dır. Damat İbrahim Paşa'yı, geleneğe aykırı olarak hızlıca veziriazam yapmıştır. Bu uygulama, sonraki padişahlar için kendilerine yakın ancak liyakati noksan adamları veziriazam yapmalarının önünü açmıştir.

Azîz Efendi (1985, s. 27), veziriazam konusunu hazine yönetimi açısından tartışır. Sultan III. Murad Han zamanına kadar devlet teşkilâtında dört vezir kadrosu bulunmakta idi ve bunlara tahsis edilecek haslar da belirliydi. Birisi vezir olduğunda bu hasları, ehil, reayaya haksızlık ve zulmetmeyen voyvodalar eliyle idare ederdi. Dört vezir her an iyi eğitim görmüş, 3000 silahlı askeri hazır bulundururdu. Şu anda yedi vezir bulunmaktadır. Vezirlerin çoğalması, hazine gelirinin azalması demektir. Üstelik bunlara hangi hasların verileceği de belirsizleşmiştir. Böyle olunca veziriazam koltuğuna oturanlar, istedikleri hasları almakta, bunları, eskiden olduğu gibi ehil voyvodalar eliyle yönetmeyip mültezime vermektedirler. Mültezimler, kötü yönetimleri ile aldıkları hasları her sene harap hale getirdiğinden, sonraki yıl bir başkasını almaktadırlar. Her birinin hazır ettiği asker sayısı da en fazla otuz-kırktır.

Vezir, insandaki akıl kudretini temsil eder (Kâtip Çelebi, 2017, s. 151). Deneyimsiz, ișini ciddiye almayan kimselerin vezirlik koltuğuna getirilmesi ise padişahı yıkıma götüren işretlerden birisi olarak görülmektedir (İpşirli, 1980, s. 257).
Hezarfen Hüseyin Efendi (1988, s. 73), padişahın, bir kimseyi veziriazam tayin ettikten sonra ona tam bağımsızlık vermesi, kendisi hakkında şikâyet olduğunda acele ile karar vermemesi, ağır bir kusuru olması durumunda hemen idamına karar vermeyip azil ve sürgün etmesi yönünde tavsiyede bulunur. Liyakatli adam bulmak o kadar kolay değildir, ola ki bu kimselere yeniden ihtiyaç duyulabilir. Veziriazam, devlet yönetiminde, sultandan sonraki en güçlü kişidir, mutlak vekâlet sahibidir. Kendisine vekâlet mührü teslim edildiğinde, tam bağımsızlık da verilmiş olur; bundan sonra getirdiği önerilerin hiçbirisinin geri çevrilmemesi kanun olmuştur.

\subsection{Ulema}

Asker, yönetici ve ulema, yönetimin üçlü saç ayağını oluşturur. Ulema, toplumdaki varlığını iki şekilde sürdürür. Birincisi medreselerde eğitim vererek, ikincisi de kadılık sisteminde üstlendiği yönetsel görevlerle (Âşık Çelebi 2018, s. 44). Osmanlı yönetim sisteminde kadılık sadece taraflar arasında davalara bakan bir makam değil, padişah adına sistemi denetleyici konumdadır. Sistemin başka alanlarındaki bozulmalar, medrese ve kadılarda da kendini hissettirmektedir. Hırzü’l Mülûk yazarı (1988, s. 190), birtakım cahil kimselerin rüşvet ve iltimasla medreselerde gerçek ulemanın önüne geçtiğini ve onları yoksul ve çaresiz bıraktığını belirtmektedir. Bu durumu, devletin geleceği açısından çok tehlikeli bulur: Ulema, insan bedenindeki kalp gibidir. Ulemanın perişan olduğu bir ülkenin harap olması kaçınılmazdır. Yazar, Zenbilli Ali Efendi örneğini hatırlatarak, şeyhülislamlık makamında oturan kişinin, ilmi derinlik ve genişlik yönünden bütün ulemanın kendisine saygı duyacağı, fukarayı gözeten, makam sahiplerinin gücünden etkilenmeyen, padişahın önünde de olsa hakikati söylemekten korkmayacak bir kimse olması gerekliliğini belirtir. Koçi Bey (2008, s. 46), Şeyhülislamın padişahın emriyle görevden alınmasını eleştirir. İyi örnek olarak Ebussud Efendi'yi zikreder. Ebussud Efendi, 29 yıl, ölümüne kadar bu makamda kalmıştır. Böyle olunca şeyhülislamlar, padișah karşısında ilim adına çekinmeksizin gerçeği söyleyebiliyorlardı.1594 yılında bu düzen bozuldu. Sunullah Efendi, birkaç defa yersiz yere şeyhülislamlık makamından azlolundu. Aynı şekilde kazaskerlerin de sık sık görevlerinden alınması, daha sonra bu makamlara gelenlerin gücünü zayıflattı, azledilme korkusu ile padişahın huzurunda gerçeği dile getiremez oldular.

Hezarfen (1988, s. 197), Osmanlı Devletinde, padişahtan sonraki en üst makamın veziriazamlık olduğunu, ancak birçok açıdan şeyhülislamın konumunun veziriazamla eşit, hatta bazı hususlarda ondan daha üstün olduğunu belirtmektedir. Halkın nezdinde veziriazam, padişahın nezdinde ise şeyhülislam öndedir. "Zira devlet umuru din üzerine bina olunur. Din asl, devlet onun fer'i gibi kurulmuştur". Bu nedenle şeyhülislamlar kusurlu bulunduklarında sadece sürgünle cezalandırılmış, hiçbir şeyhülislam idam edilmemiştir. Ayn Ali Efendi (1962, 
s. 67), veziriazamların, resmî törenlerde, şeyhülislamı kendinden üstün tuttuğunu belirtmektedir.

Birçok siyasetnâmede kadıların cahilliğine ve rüşvete bulaşmasına vurgu yapılmış ve ilmiye sisteminin bozulmasının yapısal nedenlerine işaret edilmiştir (Âşık Çelebi, 2018, s. 54; Hirzü'l Mülûk, 1988, s. 192; Mustafa Âlî, 2015, s. 356; Kitabu Mesâlih, 1988, s. 91). Kadıların niteliklerinin düşmesinin kök nedeni medreselerdeki eğitim sisteminin zayıflamasıdır. Medreselerde kadrolar iltimas ve rüșvetle elde edilir hale gelmiş, en seçkin yüksek öğretim kurumu olan Fatih Sahnı Seman medresesindeki hocalar bile cahilleşmiştir (Hırzü'l Mülûk, 1988, s. 97). Dolayısıyla buralardan yetişen kadıların niteliklerinin düşük olması doğal bir sonuçtur. Kadıların atanma sistemi ise onları vezir, beylerbeyi gibi yüksek devlet görevlileri karşısında güçsüz bırakmakta, geçim zorluğu rüşvete yöneltmektedir. Sisteme göre bir kişi atandığı yerde en fazla iki yıl görev yapmakta, görev süresi bitiminde İstanbul'a dönerek yeni görev beklemektedir. Kadılık için çok aday olması nedeniyle bu bekleme süresi bazen beş-altı yılı bulabilmektedir. Bu süre içinde başka geliri olmayan kadılar, kitaplarını satmakta, başkalarına muhtaç hale düşmektedir (Koçi Bey, 2008, s. 50.). Kitabu Mesâlih yazarı (1988, s. 92) problemi çözmek için, bütün kadıların liyakat yönüyle gözden geçirilmesini, liyakati eksik olanların sipahi kadrolarına atanarak boşta bekleyen kadılara yer açılmasını, kadıların boşta bekleme sürelerinin altı ayla sınırlandırılmasını önermektedir.

Hırzü’l Mülûk yazarı (1988, s. 191), ulemanın veziriazam ve beylerbeyine muhtaç olmamaları, saygı görmeleri için padişahı, ulema ile sohbet etmeye, onları tanımaya, mansıbları ile bizzat ilgilenmeye davet etmektedir.

\subsection{Reaya}

Kadim anlayışa göre, evren su, ateş, hava ve toprak olmak üzere dört unsurdan oluşmuştur. Bu anlayışa uygun olarak ulema toplumu da dört tabakaya ayırır (Kınalızâde 2014, s. 577; İpşirli, 1980, s. 250). Birinci tabaka, toplumun eğitimli kesimidir. İlim sahibi bu kişiler toplumda su gibidir. Su nasıl tabiatta canlılığın kaynağı ise ilim de toplum ruhunun besleyicisidir. İkinci tabaka, askerlerdir. Bunlar ateş gibidir. Onların kılıcının parıltısı olmasa ülke zulmete ve karanlığa düşer. Üçüncü tabaka; tüccar, esnaf ve sanayicilerdir. Bunlar hava hükmündedir. Bunların hareketi ile toplumda refah ve mutluluk artar. Dördüncü tabaka çiftçilerdir. Bunlar toprak hükmündedir. Toplumda gerçek değeri üretenler bu guruptur. Padişahın sorumluluğu bu dengeyi korumak; denge bir grup aleyhine bozulduğunda duruma müdahale edip yeniden adaleti sağlamaktır. Hasan Kâfi (İpşirli, 1980, s. 244), bu dengenin bozulmasına örnek olarak, kendi yaşadığı bölgede reaya ve sanat erbabının savaşa katılmaya zorlanmasını gösterir. Bu zorlama sonucu şehir ve kasaba halkı işini, mesleğini bırakmış, fiyatlar yükselmiş, memleket harap olmuştur.
Birçok siyasetnâmede tekrarlanan adalet dairesi metaforunda, reaya, zenginliği ortaya çıkaran en temel etken olarak belirtilir (Kınalızâde 2014, s. 517). Lütfi Paşa, Kanuni'nin bir sorusuna verdiği cevapta, padişahı, hâlihazırda hazinelerin dolu olmasına aldanmaması, esas hazinenin halk olduğu, halkın üretimi bırakması halinde, hazinenin kısa sürede boşalacağ ${ }_{1}$ konusunda uyarır. $K i$ tab-i Müstetab (1988, s. 21) yazarı, Lütfi Paşa'dan 70-80 yıl sonra kaleme aldığı eserinde, Lütfi Paşa'nın kötümser tahmininin gerçekleştiğini, hatta daha fazla olarak seferler için iç hazineden de para alındığını belirtir.

Lütfi Paşa (2017, s. 47) halk tabakalarının durumunu, ordu ile bağlantıları ve hazine yönetimi bağlamında değerlendirir. Bu bağlamda öncelikle gözetilmesi gereken, sınır boylarında görev yapan eşkinci, ellici ve akıncılardır. Halkın tamamı divanhane defterlerine kaydedilmiş olmalı, her otuz yılda bir kayıtlar yenilenmelidir. Halkın zulümden kaçma gerekçesi ile de olsa yer değiştirmesine izin verilmemelidir; yoksa memleket harap olur.

Halk, Allah'ın padişaha emanetidir (Kâtib Çelebi, 2016, s. 139). Padişah, kendisini halka sevdirmeli (Mustafa Âlî, 2015, s. 314), her vesile ile reayanın dilekçelerini almalı, fukaraya zulmeden yöneticiler azledilmeli, haksız yere el konulan mallar iade edilmelidir (Hırzül'l Mülûk, 1988, s. 182). Aynı uyarıyı Koçi Bey (2008, s. 131, 154) Sultan I. İbrahim'e sunduğu layihada tekrarlamakta, padişaha halkla doğrudan temasta olmasını önermektedir.

Hezarfen (1988, s. 185), saltanatın sürdürülmesinin şartlarından birisinin, padişahın kendisini askere, reayaya ve ulemaya sevdirmesi olduğunu belirtir. Kitabu Mesâlih yazarı (1980, s. 128), İstanbul'a, şikâyet için Divan-ı Hümayun'a gelen kimselerin, işlerinin aynı gün görülüp geri dönebilmeleri için öneriler sunmaktadır.

\subsection{Vergiler}

Osmanlı ekonomisini, vatandaşlar için cazip kılan hususlardan birisi, vergi sisteminin çok açık ve istikrarlı olmasıdır. Toprağı işleyen Müslüman tebaadan öşür, gayrimüslimlerden haraç alınır. Bunlar haneye yönelik vergilerdir. Müslüman olmayan tebaadan ilave olarak kişi başına cizye alınır. Bunun dışında ticaret işlerinden alınan vergiler bulunmaktadır.

Tarihçiler, vergi sistemindeki bu açıklığın Osmanlının Avrupa'daki hızlı yayılmasının nedenlerinden birisi olarak gösterir (Sayar, 2013, s. 85). Nakit olarak alınan vergiler, altın üzerinden değil gümüş para olan akçe üzerinden belirlenmiştir. Enflasyon dolayısıyla gümüşün, altın karşısında çok fazla değer kaybetmesine rağmen, reaya üzerinde ağır yük olacağından, devlet uzun süre vergileri sabit tutma yolunu tercih etmiş, enflasyon farkını hazine üstlenmiştir. Reaya açısından, standart dışı sayılabilecek iki vergi türü bulunmakta idi: Nüzul ve avariz vergileri. Nüzûl vergisi, ordunun sefere giderken konaklayacağ yerlerdeki iașesinin hazırlanması için alınan bir vergidir. Avarız ise, olağanüstü durumlarda alınan geçici bir vergi. 
Ne var ki bu iki vergi de gelirlerin yetersizliği nedeniyle bir süre sonra kalıcı hale dönüşmüş, reaya üzerinde büyük yük oluşturmuştur (Koçi Bey, 2008, s. 63). Mustafa Âlî (2015, s. 183), nüzul ve avariz vergilerinin varlığını değil, uygulamacıların tutum ve davranışlarını eleştirmektedir. Ayn Ali (1962) ve Hezarfen Hüseyin Efendi (1998), uygulanan vergilere ve vergilendirme usulüne dair ayrıntılı bilgiler vermektedirler.

Âşık Çelebi (2014, s. 204), İslam'a göre gayrimüslimlere yönelik vergi hukukunu ayrıntıları ile açıklar, bazı kadıların cehaletlerinden dolayı halka zulmettiklerinden yakınır. Kitabu Meslaih yazarı (1988, s. 108), vergi uygulamalarında gayrimüslim tebaanın maruz kaldığı bazı haksızlıkları dile getirerek bunların ortadan kaldırılmaSinı ister.

\subsection{Askerin Durumu}

Siyasetnâmelerde askerin durumu, birbiriyle sebep sonuç ilişkisi olan üç açıdan tartışma konusu olmaktadır. Birincisi maaşlı asker sayısının artması, ikincisi yeniçeriliğe giriş sisteminin bozulması, üçüncüsü de askerin liyakati. Lütfi Paşa (2017: 40), maaşlı asker sayısının çoğalmış olmasına ve timar sahiplerinin bizzat sefere katılmalarının gerekliliğine vurgu yapar. Asker içinde cebelü sayısının artmasını doğru bulmadığını belirtir. Hasan Kâfi (İpşirli, 1980, s. 275), 1596'da yazdığı eserinde, askerin hem nitelik hem de davranışlarına yönelik eleştirilerde bulunur. Osmanlı askerin eğitimi ve kullandıkları silahlar düşmanlarından geri kalmış durumdadır, bu yüzden de yenilgiye uğramaktadır. İkinci olarak, maaşlı askerler, Rumeli'de Müslüman halka zulmetmektedirler.

Kitâb-i Müstetab yazarı (1988, s. 9-11), 1620 yılında kaleme aldığı eserinde, askerin durumu ile ilgili oldukça karamsar bir tablo çizer. Zeametlerdeki askerlerin sadece kâğıt üstünde var olduğunu, kayıtlarda görünen asker sayısının ordunun gerçek savaş kapasitesini yansıtmadığını belirtir. Kayıtlarda 35 binden fazla görünen yeniçeri askerinden, ancak 20 bini savaşabilecek durumdadır. Kalanlarının kimisi koruculuk, kimisi kalelerde nöbetçilik yapmaktadır. Bir kısmının yaşı küçük, bir kısmı ise emekli statüsündedir. Azîz Efendi (1980, s. 31), 1621 yılında, maaşlı asker sayısının 100 bin kişiyi aştığını, buna karşılık niteliklerinin çok düşük olduğunu, gerçek bir elemeden sonra, ancak 30-40 bin işe yarar askerin çıkabileceğini belirtmektedir. Yazar, elemenin nasıl yapıla- cağına dair ayrıntılı bir uygulama planı da sunmaktadır.

Kitâb-i Müstetab yazarı (1988, s. 10), yeniçerilik sistemindeki bozulmayı değerlendirirken koruculuk ayrıntısına değinir. Yeniçeri geleneğinde bu tür kadrolar, savaşta işgöremeyen yeniçerileri kollamak için kullanılırdı. Oysa şimdikiler bu kadroları savaştan kaçmak için kullanmaktadır. Bu kadroların tamamı rüşvetle verilmekte ve bu durum hazine için büyük yük oluşturmaktadır. Aziz Efendi (1984, s. 32) 1640'ta, saraydaki muhafiz sayısını eleștirerek, koruculuk sisteminin bütünüyle kaldırılmasını önerir.

Yazarlar, yeniçerilik sisteminin, kanun-ı kadime aykırı olarak sisteme yabancıların alınması nedeniyle bozulduğunda hemfikridirler. Koçi Bey (2008, s. 59) Yeniçeri Ocağı'nın bozulma tarihini 1503 olarak kaydeder. Bu tarihte Sultan III. Mehmed'in çocuklarının sünnet düğününde halkı eğlendiren kişiler Yeniçeri Ocağına girmek istediler. Yeniçerilerin başkanı Ferhad Ağa'nın karşı çıkmasına rağmen padişah bu isteği kabul eder. Bu kişiler "ağa çırağı" namıyla ocağa kaydedilir. Sonraki yıllarda buna, "sipahi oğlu" adıyla sipahilerin çocuklarının acemi ocağına kaydedilmesi uygulaması da eklenmiştir.

Hem Koçi Bey (2008, s. 90) hem de Azîz Efendi (1985, s. 30-33), yeniçeri sisteminin nasıl düzeltileceğine dair ayrıntılı uygulama planlarını sunmuşlardır. Kitabu Mesâlih yazarı (1988, s. 93-100), askeri sistemin işleyişiyle ilgili, alışılagelmiş sistemi zorlayacak önerilerde bulunur. Devşirme çocukların Türk ailesinin yanına verilmesi yerine doğrudan bölüklere gönderilip kendilerine askerlik sanatına dair beceriler kazandırılması, her gün odalarında âtıl vaziyette duran yeniçerilere, matrak oynama, binicilik gibi dersler verilmesi, sipahilerin sadak torbalarını terk ederek daha hafif silahlar kullanmaları bu önerilerden bazılarıdır.

Hezarfen (1988, s. 90), 1675 yılında toplam yeniçeri sayısının 54.200 olduğunu belirtmektedir. Yazar, yıllar içindeki toplam asker sayısındaki değişimi de verir. Kanuni döneminde 48.316, III. Murad döneminde 64.175, kitabın yazıldığ 1080 (1675) tarihinde ise toplam 94.999 asker bulunmaktadır. Hezarfen, asker sayısını azaltarak, Kanuni dönemindeki miktara indirmenin mümkün olamayacağını, askerin çokluğunu bir olarak görmemek gerektiğini belirtir. Esas olarak kanun-1 kadime uyarak, israfı ve masrafları azaltmak gerekir (s. 105). Ayn Ali

Tablo 3. Yıllara Göre Maaşlı Askerlere Yapılan Ödemeler

\begin{tabular}{|c|c|c|c|c|}
\hline Yil & Padişah & $\begin{array}{c}\text { Toplam Maaşlı Asker } \\
\text { Sayısı }\end{array}$ & $\begin{array}{c}\text { Toplam Yıllık Ödeme } \\
\text { Tutarı (Akçe) }\end{array}$ & $\begin{array}{c}\text { Kişi başına Yıllık Ödeme } \\
\text { (Akçe) }\end{array}$ \\
\hline 1566 & Kanuni & 48.316 & 126.409 .000 & 2.616 \\
\hline 1588 & III. Murad & 64.175 & 178.200 .000 & 2.777 \\
\hline 1602 & I. Ahmed & 91.200 & 380.000 .000 & 4.167 \\
\hline $1618-1623$ & II. Osman-III. Mustafa Dönemleri & 100.000 & ..- & -.. \\
\hline $1623-1640$ & IV. Murad & 59.257 & 263.100 .000 & 4.440 \\
\hline 1664 & IV. Mehmed & 94.999 & 308.693 .500 & 3.249 \\
\hline
\end{tabular}

Kaynak: Hezarfen, 2019, s. 105. Kitaptaki veriler yazarlar tarafından tablo haline getirilmiştir. 
Efendi (1962, s. 35) ve Hezarfen Hüseyin Efendi (1988, s. 104-106)'inin eserlerinde askerlerin aldıkları maaşlar ve yıllar içinde asker sayısının nasıl değiștiğine dair ayrıntılı açıklamalar bulunmaktadır.

IV. Murad döneminde asker sayısında hızlı bir düşüş gerçekleştiği, kendisinden sonra gelen IV. Mehmed öneminde asker sayısının yeniden eski haline döndüğü görülmektedir.

\subsection{Adalet}

Adalet, toplumsal yapının devamlılığında hem sebep hem sonuçtur. Bu ilişkiyi açıklamak için daire metaforu kullanılır: Adalet hazinenin gelirini çoğaltır; gelir ancak bayındır bir memlekette olur; bir ülke harap olduğunda halk da yoksullaşır; bayındırlık ancak adaletle sağlanır (Kınalızade, 2014, s. 574; Aziz Efendi, 1980; Kitâb-i Müstetab 1988, s. 18; Katip Çelebi, 2016, s. 139). Daire, başlangıcı ve sonu belirli olmayan bir sembol olduğu için burada sıralanan unsurlardan hangisinin sebep, hangisinin sonuç olduğunu belirlemek kolay değildir (Oktay, 2015, s. 470-474).

Adaletin uygulanması kadılar aracılığıyla gerçekleştirilir. Ancak adaletin uygulanmasından bizzat padişah sorumludur, diğerleri ona vekâleten iş görürler. Başkalarına vekâlet vermiş olması padişahı sorumluluktan kurtarmaz (Mustafa Âlî, 2015, s. 283; Hezarfen 1988, s. 113). Bu anlayışla, İslam medeniyetinde padişahların yargılamalara bizzat katılmaları güçlü bir gelenektir. Kanuni’ye kadar Osmanlı padişahları da yargılama divanına bizzat katılmışlar, daha sonra toplantıları perde gerisinden izlemeye devam etmişlerdir (Koçi Bey 2008, s. 149; Hezarfen 1988, 7s. 5). Adalet sistemindeki bozulma, adalet dairesi metaforu gereği, saltanatın yıkımı ile sonuçlanır (Hasan Kâfi 1980, s. 251).

Adaletin uygulanabilmesi için, padişahın halkla teması, halkın şikâyetlerini dinlemesi önemlidir. Vezirler, padişahın halkla buluşması için zemin hazırlamalıdır (Lütfi Paşa, 2017, s. 58). Bunun için padişah, hiç değilse haftada bir gününü, halkın şikâyet ve talebi dinlemeye ayırmalıdır (Kınalızâde, 2014, s. 590; Koçi Bey, 2008, s. 41).

\subsection{Rüşvet}

Rüşvet olgusu, Kınalızade (2014, s. 588) ve Lütfi Paşa (2017, s. 33)'nın eserlerinde sadece kaçınılması gereken davranış olarak vurgulanır, makam sahiplerine verilecek hediyelerin bile rüşvet sayılabileceği belirtilir. Koçi Bey (2008, s. 64), rüşvetin başlangıç tarihi olarak 1581 yılını vermektedir. Başka yazarların da verdikleri örneklere göre mansıblar, timar ve zeametler, rüşvetle alınıp satılmakta, beylerbeyi ve kadı gibi kadrolarda görev yapanlar da rüşvete bulaşmış durumdadır (Hırzü'l Mülûk, 1988, s. 187; Mustafa Âlî 2016, s. 342; Kitabu Mesâlih, 1988, s. 105). Kâtib Çelebi (2016, s. 144), rüşvetin artık normal bir işleyiş haline geldiğini belirtmektedir. Öyle ki, Kitâb-i Müstetab yazarı (1988, s. 24), rüşvetin ülke çapında ve bütün makam sahiplerini kapsayacak şekilde yaygınlaştığından şikâyet eder. Memurların bu tutumu karşısında halk Celalileri bile hayırla anar olmuştur. Yazar, padişahın acilen duruma el koyması için, adeta çığlık atar: "Verdi divan ehli rüşvetle cihana ihtilal / Padişahım ettiler vallahi mülkün payimal / Aşikâre bey' iderler kahbe-zenler mansıbı / Nice kopmasın Celali nice olmasın kıtal." "Padişahım kıl tefahhus muttali ol devlete / Yoksa âlem gitti, ıslah olmadan oldu baid”.

Koçi Bey (2008, s. 77-78), Rüşveti ortadan kaldırmak için yapısal çözümler önerir. Koçi Bey’in önerileri, başka siyasetnâme yazarlarında da geçen önerilerdir. Buna göre; (1) Veziriazam bağımsız olmalı. (2) Beylerbeyleri, somut bir kusuru olmadikça görevlerinden azledilmemeli, ömür boyu görevde kalmalı. (3) Zeamet ve timarlar beylerbeyleri tarafından dağıtılmalı. (4) İlim mansıbları ehline verilmeli, cahil olanlar medreseden çıkartılmalı. (5) Paşmaklıklar zeamet ve timarlardan değil, padişaha ait haslardan verilmeli. (6) Sarayda görevli kapıcıbaşılara arpalık olarak zeamet ve timar arazileri verilmemeli. (7) Sarayda görevli kâtipler liyakat sahibi olmalı. (8) Saraydaki ihtiyaç fazlası görevliler, kendilerine zeamet ve timar verilerek kadroları iptal edilmeli. (9) Zeamet ve timar sahiplerine ait yaş ve eşkâl bilgileri çıkarılmalı, daha sonra bunlar kontrol edilerek bu haklarını başkalarına devretmeleri engellenmeli.

\section{TARTIŞMA}

Siyasetnâmeler, dönemin toplum yapısı, devletin örgütlenme biçimi, ekonomik yapı, devletin toplumla ilişkisi gibi birçok alan için veri sağlayan belgelerdir. Bu makalede incelediğimiz, 16. ve 17. yüzyıllarda Türkçe olarak yazılmış siyasetnâmelerden yola çıkarak dönemin öne çıkan yönetim anlayışı ortaya konulmaya çalışılmıştır. İncelenen eserlere içerik olarak baktığımızda, 15 siyasetnameden 14'ünün ıslahatnâme tarzında olduğu görülmektedir.

Siyasetname yazarlarının yetişme tarzları ve mesleklerine batığımızda, bilinebildiği kadarıyla, üçü ilmiye sınıfı mensubu (Kınalızâde Ali Efendi, Âşılk Çelebi, Hasan Kâfî), ikisi ilmiye kökenli bürokrat (Gelibolulu Mustafa Âlî, Kitabu Mesâlih yazarı), dördü bürokrat (Avni Ömer Efendi, Ayn Ali Efendi, Kâtib Çelebi, Hezarfen Hüseyin Efendi), ikisi danışman (Aziz Efendi, Koçi Bey) ve biri veziriazamdır. Osmanlı Devleti, dünyada çok erken dönemde yönetim okulu oluşturarak, buradan kamu yöneticisi yetiştiren iki devletten birisidir (Bayraktar ve Alayoğlu 2016, s. 96). Enderun'dan yaklaşık 250 yıl boyunca çok sayıda, yüksek nitelikli yönetici yetişmiş ve devletin en üst kademesi olan veziriazamlık görevini üstlenmişlerdir. Buna karşılık iki yüz yıl içinde, yönetime ilişkin Türkçe olarak sadece 15 eser üretilmiş olması üzerinde durulmaya değer bir konudur. Eser sayısının az olmasının iki nedeni olduğu düşünülebilir. Birincisi, yazılmış olan eserlerin henüz günyüzüne çıkmamış olmasıdır. 
Bir araștırmada, sadece İstanbul kütüphanelerinde 269 siyasetnâme olduğu belirtilmiştir (Yılmaz, 2009, s. 308). İncelediğimiz 15 siyasetnâmeden 10'un orijinal kopyasının yurtdışı kütüphanelerde bulunduğu belirtilmektedir. Tarihçilerimiz kütüphanelerde yazılı halde bulunan eserleri günyüzüne çıkardıklarında siyasetnâme yazının genişlemesi beklenebilir. İkinci olasılık, Enderun Okulunda yönetimin uygulanmasının iyi öğretildiği, ancak eser yazma konusunda aynı derecede heves gösterilmemiş olmasıdır. Eserlerini incelediğimiz yazarlardan sadece ikisi; Lütfi Paşa ve Koçi Bey Enderun kökenlidir.

Siyasetnâmelerin yazım tarihlerine bakıldığında, 1580'den sonra yoğunluk olduğu görülmektedir. Siyasetnâme talebinin ortaya çıkması, yönetim problemlerinin artması ile doğrudan bağlantılı olmalıdır. Siyasetnâmelerde işlenen ortak temalar izlendiğinde, timar ve zeamet sistemindeki çözülmenin birçok problemin ana kaynağ olarak ele alındığı, görülmektedir. Bunu izleyen problemler, veziriazamın tutumu, ulamanın durumu, maaşlı asker sayısındaki artış, reayanın dururumu, hazine gelirlerinin giderleri karşılamaması başlıklarıdır. Bürokraside rüşvetin yaygınlaşması ve vakıf sisteminin, devletin dayandığı toprak rejimini zorlayacak biçimde istismar edilmesi üçüncü derecede problemler olarak belirmektedir.

Siyasetnâmalerde, diğer yöneticilerin padişahın vekili olduğu, onun adına iş gördükleri, ortaya çıkan kusurlardan padişahın sorumlu olduğu cesaretle hatırlatılmakta, ancak hiçbir şekilde padişahın konumu ve şahsına yönelik bir eleştiri yer almamaktadır. Yazarlar, padişahtan beklentilerini daha çok geçmiş padişahların iyi ve kötü davranışlarını hatırlatarak dolaylı olarak dile getirmektedir.

Siyasetnâme yazarlarının problemlerin kaynağı olarak iç sistemlere odaklandıkları, problemlerin geride kalan ideal uygulamalara dönülerek çözülebileceği görüşünde oldukları görülmektedir. Devletin giderleri arttıkça, hazineye gelir sağlama baskısı daha da acil hale geliyordu. Bu durumda bütün dikkatler ülkede vergi geliri üreten kaynak olan toprak sistemine yöneliyordu. Ne var ki topraktan elde edilebilecek gelir sinırlı, hatta nüfusa göre azalmakta idi (Küçükömer, 2007, s. 21). 1595-1650 yılları arasında toplumu ve devletin işleyişini derinden sarsan Celali isyanları siyasetnâmelerde kendisine çok az yer bulabilmiştir. Aynı şekilde, sonraki yıllarda da Osmanlıyı derinden etkileyecek olan Avrupa'daki birtakım gelişmeler, yenilikler, coğrafi keşifler de siyasetnâme yazarlarının ilgi alanına girmemiştir. Yılmaz (2009, s. 308), özellikle bir kısım siyasetnâme yazarlarının dış çevredeki bu gelişmelerden habersiz olmalarının düşünülemeyeceğini, buna rağmen bu konulara ilgisiz kalmalarının zihniyet dünyalarıyla açıklanabileceğini belirtmektedir. Onlar, mevcut sistemin en iyi sistem olduğuna inanmakta, bu nedenle problemlere çözümü, yine kendi yönetim deneyimlerinde aramaktadırlar. Osmanlı yöneticileri ve aydınları, Tanzimat'a gelinceye kadar, sayıca çok az ancak etkili iktisat politikası araçları kullanmışlardır.
Bunlar toprak rejimi, vergileme, sikke tağşişi ve narh sistemidir (Sayar 2013, s. 71). İnceleme konusu yaptığımız siyasetnâme yazarlarının yaklaşımları da bu çerçevede kalmaktadır.

Problemlerin çözümü için, kanun-1 kadime dönme düşüncesi, yazarların zihni sınırlarını belirleyici niteliktedir. Geçmişte o kadar uzun süreli parlak uygulamalar vardır ki, sanki bütün problemlerin çözümü yeniden oraya dönmekle mümkün olabilecek gibi görünmektedir. Kâtip Çelebi, genel yaklaşımdan farklı olarak, problemi tarih sosyolojisi bağlamında ele almaktadır. Ona göre, devletin yaşı dikkate alındığında, maaşlı asker sayısının azaltılması, saraydaki masrafların kısılması gibi öneriler uygulanabilirlikten uzaktır. Yeni koşullara uygun çözümler üretilmesi gereğine inanmaktadır. Ancak Kâtip Çelebi de bu yaklaşımını derinleştirerek, diğer yazarlardan farklı sayılabilecek öneriler getirmemiştir. Kâtip Çelebi gibi sistematik düşünce ortaya koymamakla birlikte, Ayn Ali Efendi ve Hezarfen Hüseyin Efendi de asker sayısının azaltılabileceği görüşünü uygulanabilirlikten uzak olarak değerlendirmektedirler. $\mathrm{Bu}$ yazarların dışında, Hasan Kâfi, silah sisteminin, düşmanların gelişmelerini dikkate alınarak yenilenmesi, Kitabu Mesâlih yazarı, asker kıyafetleri, askerin silahları, yeniçerilerin eğitimleri gibi konularda kanun-i kadimin dışına çıkılması önerilerinde bulunmuşlardır.

Siyasetnâmelerin yöneticiler üzerindeki etkilerini görmek için bu eserleri dönemin tarihi olayların gelişimi ile birlikte değerlendirmek gerekir. Bu açıdan bakıldığında, tarihçiler Kitâb-i Müstetab'ın, II. Osman'ın tutumu, Koçi Bey'in risalelerinin IV. Murad ve I. İbrahim'in tutumları üzerinde etkisi olduğunu bildirmektedirler. Etkiyi anlamak için kullanılabilecek ikinci ölçüt, eserlerin başka yazarlar üzerindeki etkisidir. Bu açıdan bakıldığında, Kınalızâde'nin Ahlak-ı Âlaî’sinin son dönemlere kadar Osmanlı medreselerinde ders kitabı olarak okutulduğu, Lütfi Paşa'nın Asafnâme'sinin, kendinden sonra yazılan çok sayıda siyasetnâmeye kaynaklık ettiği bildirilmektedir.

Günümüz dünyasında hem örgüt yönetimi hem kamu yönetimi alanında çok büyük bilgi birikimi sağlanmış durumdadır. Dünyanın hiçbir yerinde yöneticiler açısından bilgi eksikliğinden söz edilemez. Yönetimde başarı için iki şart bulunmaktadır. Birincisi bu büyük bilgi yığ ${ }^{-}$ nın yöneticinin içinde bulunduğu koşullara göre özümsenip özelleştirilmesi. Kurumsal yapılar içinde oluşan kurmay birimler önemli ölçüde bu gereksinimi karşılamakta, bilgi birikimini kendi kurumları için özel hale getirmektedirler. İkinci aşama bu bilginin yöneticinin ihtiyaç ve beklentilerine göre daraltılmasıdır. Burada yönetici açısından iki tür ilişki biçimi mümkündür. Birincisi, yönetici ile kişisel ilişkisi olmasa da konuya özel olarak uzmanlardan alınan raporlar. Geçmişte olduğu gibi günümüzde de bu sistem işlemektedir. Günümüzde her kurum bedelini ödeyerek danışmanlık hizmeti alabil- 
mekte; danıșmanlık kuruluşları da bedelini her ödeyene bu hizmeti sunabilmektedir. Bilginin yöneticiye özel hale getirilmesinde ikinci aşama, yöneticinin bizatihi yanında bulundurmayı arzu ettiği, doğrudan yönetim görevi olmayan ancak entelektüel donanım sahibi sohbet arkadaşlarıdır. Geçmiş dönemde padişahların etrafındaki musahipler, doğrudan yönetim görevi olmayan, entelektüel donanım sahibi sohbet arkadaşları bu işlevi yerine getirmekte idiler. Bu aşamada esas olan yöneticinin bilgiyi aktaran kişiye, sırlarını onunla paylaşabilecek kadar güven duymasıdır. Bütün bunlar olsa da en nihayetinde yönetim becerisi, bilgiyle sanatın kesiştiği bir alandır. Sonucu belirleyecek olacak bizatihi yöneticinin bilgiyi uygulama kapasitesidir. Bu aşamada hızlı karar verme, yüksek sezgi gücü, kararlılık, feraset, izleyicilerle kurulan ilişkinin niteliği gibi kişisel özellikler belirleyicidir.

\section{SONUÇ VE ÖNERILER}

Siyasetnâmelerin birinci işlevi, yöneticiye, bütün toplumun paylaştı̆̆ı üst değerler çerçevesinde görevini hatırlatmaktır. Bu makalede inceleme konusu yaptığımız eserlerde, devlet başkanı bir değerler sistemi içerisine yerleştirilir. Bu değerler sisteminin en başında Tanrı ve ilahi kanun vardır. Hükümdar yeryüzünde Allah'ın gölgesidir. Bu sorumlulukla adaleti uygulamak, tebaayı gözetmekle yükümlüdür. Sanıldığı gibi bu durum, devlet başkanına yönetimde istediği gibi özgür davranma, istediği düzenlemeleri yapabilme hakkını tanımaz. Onun devleti ve toplumu yönetirken yapabileceği düzenlemeler ancak kendisine bırakılan alanla ilgilidir. Bu değerler sisteminin kalmadığı bir ortamda geleneksel tarzda siyasetnâme yazmak anlamlı değildir. Siyasetnâmelerin ikinci işlevi, yöneticiye, yönetim işlevine ilişkin genel bilgiler aktarmaktır. Günümüzde yönetim eğitiminin yaygınlığı düşünüldüğünde bu işlevin anlamını yitirdiğini söyleyebiliriz. Siyasetnâmalerin, sslahatnâmeye dönüștükten sonraki işlevi ise, yöneticilere belirli problemlerin nasıl çözüleceğine dair yol göstermektir. Günümüzde, yöneticiler kendilerine bu tür raporlar sunan çok sayıda danışman istihdam etmektedir.

Bütün bunlara rağmen, yazarlık, yazma kudreti, sadece bilimsel bir formasyon değil, sanatla bütünleşik bir yeteneğe sahip olma durumudur. Nesnel koşullar dikkate alındığında, etkili olması, 300-400 yıl önceki kadar kolay olmamakla birlikte, yöntemi bilgisi ve yazma kudretine sahip yazarın, bugünün dili ve kavrayıșıyla, bugünün yöneticilerine yol gösterecek eserler ortaya koymasının önünü de hiç kimse kapatamaz.

Bu araştırmada 16. ve 17. yüzyıllarda ortaya konulan siyasetnameler incelenmiștir. 18. ve 19. yüzyıllarda Osmanlı Devletinin yönetim problemleri daha da derinleşmiştir. Başka araştırmacılar, 18. ve 19. yüzyıllarda üretilen siyasetnamelerde hangi konuların öne çıktığını, yazarların zihni çerçevelerinin nasıl değiştiğini inceleyebilirler.

\section{KAYNAKÇA}

Adalığlu, H. H. (2009). Siyasetname. DiA (C. 37, ss. 306-308). İstanbul: TDV Yayınları.

Afyoncu, E. (2013). Ayn Ali Hakkında Yeni Bilgiler. Journal of Turkish Studies, 39. 95-128.

Akdağ, M. (1975). Türk Halkının Dirlik ve Düzenlik Kavgası. Ankara: Bilgi Yay.

Akün, Ö. F. (2002). Koçi Bey. DiA (C. 26, ss. 143-148). İstanbul: TDV Yayınları.

Ali Emirî. (2017). Tadkdîm. Lütfi Paşa, Asâfnâme içinde, (15-21), İstanbul: Büyüyenay Yayınları.

Âşık Çelebi. (2018). Mi'râcü'l-Eyâle. (M. U. Onuş ve A. Bulut, Haz.). İstanbul: Türkiye Yazma Eserler Kurumu.

Ayni Ali Efendi (1962). Kanunname-i Âl-i Osman. (Tuncer, H., Haz.). Ankara: Tarım Bakanlığı Yay.

Aziz Efendi (1985). Kânûn-nâme-i Sultânî Li Azîz Efendi. (Murphey, R., Haz.). Harvard: Harvard Üniversitesi Yayınları.

Bayraktar, O. ve Alayoğlu, N. (2018). Günümüz Örgütleri Iç̧in Yetenek Yönetimi Modeli Önerisi: Devşirme Sistemi. Amme Idaresi Dergisi, 51(3), 89-119.

Blaydes, L., Grimmer, J. ve McQueen, A. (2018). Mirrors for Princes and Sultans: Advice on the Art of Governance in the Medieval Christian and Islamic Worlds. The Journal of Politics, 80 (4), 1150-1167.

Dinçer, Ö. (2018). Siyasetnâmeleri Yeniden Okumak. İstanbul: Klasik Yay.

Elo, S., Kääriäinen, M., Kanste, Q., Pölkki, T., Utriainen, K. ve Kyngäs, H. (2014). Qualitative Content Analysis: A Focus on Trustworthiness, Sage Open. 1-10.

Emecen, F. M. (2007). Osman II. İslâm Ansiklopedisi (C. 33, ss. 453-456), İstanbul: TDV.

Emecen, F. M. (2000). İbrahim. DiA (C. 21, ss. 274-281), İstanbul: TDV Yayınları.

Gelibolulu Mustafa Âlî (2015). Siyaset Sanatı - Nushatü's Selâtîn (Çerçi, F., Çev.). İstanbul: Büyüyenay Yay.

Gökyay, O. Ş. (1994). Düstûrü'l-Amel. İslâm Ansiklopedisi (C. 10, ss. 50-51), İstanbul: TDV Yayınları.

Halaçoğlu, Y. (2012). Ulak. DiA (C. 42, ss. 77-79). İstanbul: TDV Yayınları.

Hezarfen Hüseyin Efendi. (1998). Telhîsül'I-beyân fî kavânîn-i Âl-i Osmân. (ilgürel,S., Düz.). Ankara: Türk Tarih Kurumu Yayınları.

Hırzü'l Mülûk. (1988). Osmanlı Devlet Teşkilâtına Dair Kaynaklar içinde, (Yücel, Y., Haz.) Ankara: Türk Tarih Kurumu Yayınları.

Hsieh, H. F. ve Shannon, S. E. (2005). Three Approaches to Qualitative Content Analysis. Qualitative Health Research. 15(9), 1277-1288.

İlgürel, M. (1993). Celâlî İsyanları. DiA (C. 7, ss. 252-257), İstanbul: TDV Yayınları.

İpşirli, M. (1979-1980). Hasan Kâfî El-Hisarî ve Devlet Düzenine Ait Eseri Usûlü'l hikem fî nizâmi'l âlem, Tarih Enstitüsü Dergisi, 10-11, 239-278.

İpşirli, M. (1999). Islahat. DiA (C. 19, ss. 174-185). İstanbul: TDV Yayınları. 
Kahraman, A. (1989). Ahlâk-ı Alâî. DiA (C. 2, ss15-16), İstanbul: TDV Yayınları.

Karaismailoğlu, A. (2002). Kelile ve Dimne. İslâm Ansiklopedisi (C.25, ss. 210-212), İstanbul: TDV Yayınları.

Kınalızâde Ali Çelebi (2014). Ahlâk-ı Alâ'î. (Unan, F., Haz.). Ankara: Türk Tarih Kurumu Yayınları.

Kitab-i Müstetab (1988). (Osmanlı Devlet Teşkilatına Dair Kaynaklar içinde, (Yücel, Y., Haz.). Ankara: Türk Tarih Kurumu Yayınları.

Kitabu Mesâihi'l Müslimîn ve Menâfii'l Mü'minîn (1988). (Osmanlı Devleti Teşkilatında Dair Kaynaklar içinde, (Yücel, Y., Haz.), Ankara: Türk Tarih Kurumu Yayınları.

Köksal, A. C. (2017). Bir İslâm Âlimi Olarak Lütfi Paşa. Osmanlı Araştırmaları, 50, 29-72.

Küçükömer, İ. (2007). Düzenin Yabancılaşması. İstanbul: Bağlam Yayıncilık.

Kütükoğlu, M. S. (2003). Lâyiha. İslâm Ansiklopedisi (C. 27, ss. 116-117), İstanbul: TDV Yayınları.

Lütfi Paşa (2017). Asafnâme. (Ahmet Uğur, Haz.), İstanbul: Büyüyenay Yayınları.

Murphey, R. (1985). Kânûnnâme-i Sultânî Li Azîz Efendi. Harvard: Harvard Üniversitesi Yay.

Naki, E. (2016). XVI. Yüzyılda Latin Amerika Gümüşünün Osmanlı-İspanyol Rekabetindeki İktisadi Rolüne Dair Bazı Düşünceler. Çanakkale Araştırmaları Türk Yıllığı, 14(16), 229-247.

Oktay, A. S. (2015). Kınalızâde Ali Efendi ve Ahlâk-ı Alâî. İstanbul: İz Yayıncilık.

Sayar, A. G. (2013). Osmanlı Iktisat Düşüncesinin Çağdaşlaşması. İstanbul: Ötüken Yayınevi.

Unan, F. (2014). Kınalı-zâde Ali Çelebi: Hayatı ve Ahlâk-ı Alâ'i'si, Ahlak-ı Alâ'î içinde. Ankara: Türk Tarih Kurumu. XIIILXVIII.

White, M. D. ve Marsh, E.E. (2006). Content Analysis: A Flexible Methodology. Library Trends, 55(1), 22-45.

Yılmaz, C. (2003). Osmanlı Siyaset Düşüncesi Kaynakları ile İlgili Yeni Bir Kavramsallaştırma: Islahatnâmeler. Türkiye Araştırmaları Literatür Dergisi, 1(2). ss.299-338.

Yılmaz, C. (2009). Siyasetname. DiA (C. 36, ss. 36-38), İstanbul: TDV Yayınları.

Yücel, Y. (1988). Osmanlı Devleti Teşkilâtına Dair Kaynaklar. Ankara: Türk Tarih Kurumu Yayınları. 